\title{
Distribution of Lizards of the Absheron Peninsula
}

Najafov JA ${ }^{*}$ and Hashimov RT2

${ }^{1}$ Baku State University, Azerbaijan

${ }^{2}$ Azerbaijan Medical University, Azerbaijan

*Corresponding author: Najafov JA, Baku State University, Azerbaijan, Tel: +994 12

59559 29; Email: canbaxish@gmail.com

\section{Review Article}

Volume 2 Issue 3

Received Date: April 22, 2019

Published Date: May 14, 2019

DOI: $10.23880 /$ izab-16000147

\section{Abstract}

60 species of reptiles live in the Azerbaijan Republic. From them 17 species, or 28.3\% are spread on Absheron Peninsula. These species belong to 3 orders, 13 families, 22 genera. Lizards are reptiles belonging to the order Squamata. On Absheron peninsula lizards inhabit a wide variety of biotopes, from garden habitats to sand dunes. Most species of Absheron are diurnal, but Caspian bent-toed geckos comprise a night time fauna in many habitats. Many species, can shed their tails in order to escape from predators. Lizards have many morphological adaptations that suit them to the substrates they inhabit, from specialized toe-pads in vertical rock-face dwellers to fringed-toes in loose-sand runners. Modern scientific study of lizards in Absheron began with the field natural history studies of E.P. Menetriem and E.E. Eichwald in the 19 th century.

Keywords: Absheron Peninsula; Ecology; Lizard; Environmental Condition; Map

\section{Introduction}

Absheron is the largest peninsula in Azerbaijan, located on the western coast of the Caspian Sea. The peninsula, with its climatic and relief index, has good conditions for different species of reptiles, so it has rich lizard members. However, territory of Absheron is exposed to ever-increasing anthropogenic influence. Research of distribution and ecology of lizard populations are necessary for solving one of global problems of our time preservation and use of biological diversity as the basis for the sustainability of the biosphere.

\section{Materials and Methods}

In 2007-2018, we studied the distribution of lizards on Absheron peninsula and compiled the corresponding maps. In order to discover habitats of lizards on Absheron peninsula, we organized an expedition and studied herpetological collection of the Institute of Zoology of National Academy of Sciences of Azerbaijan. Activity of lizards was investigated at different times of day and in certain months of year. During the expeditions, we found 823 individuals of different species of lizards, among which were: 746 individuals of Cyrtopodion caspius, 427 Ophisops elegan, 298 Eremias velox, 226 Lacerta strigata, 109 Eremias arguta, 87 Laudakia caucasia, 41 Eumeces schneideri. In addition, all studies which were carried out before us for detection of this species were reviewed, and all literature data were studied.

\section{Result and Discussion}

From the Lacertidae family on Absheron Peninsula, there are 4 species-Eremias velox, Eremias arguta, Ophisops elegans and Lacerta strigata that makes about 


\section{International Journal of Zoology and Animal Biology}

$57,1 \%$ of lizards, which live on this peninsula. From families Agamidae, Scincidae and Gekkonidae, there is one species of lizard Laudakia caucasia Eichwald, 1831, Eumeces schneideri and Cyrtopodion caspius, each makes up about $14,3 \%$ of total number of lizard species (Figure 1).

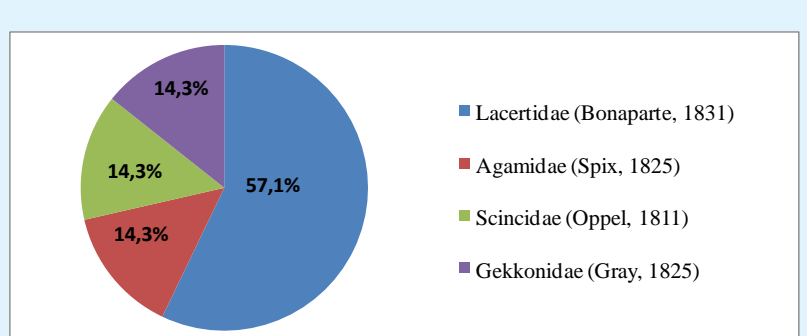

Figure 1: Percentages of families by spaces on Absheron peninsula.

Caspian bent-toed gecko Cyrtopodion caspius (Map 1): It is one of the most common nocturnal lizards of Azerbaijan (Figure 2). This species was first discovered in 1831 by E.E. Eichwald on mountains of Baku. Caspian bent-toed gecko is a small sized lizard of Gekkonidae; it is distributed in many cities and villages in Absheron. Cyrtopodion caspius caspius and Cyrtopodion caspius insularis inhabits on the peninsula.

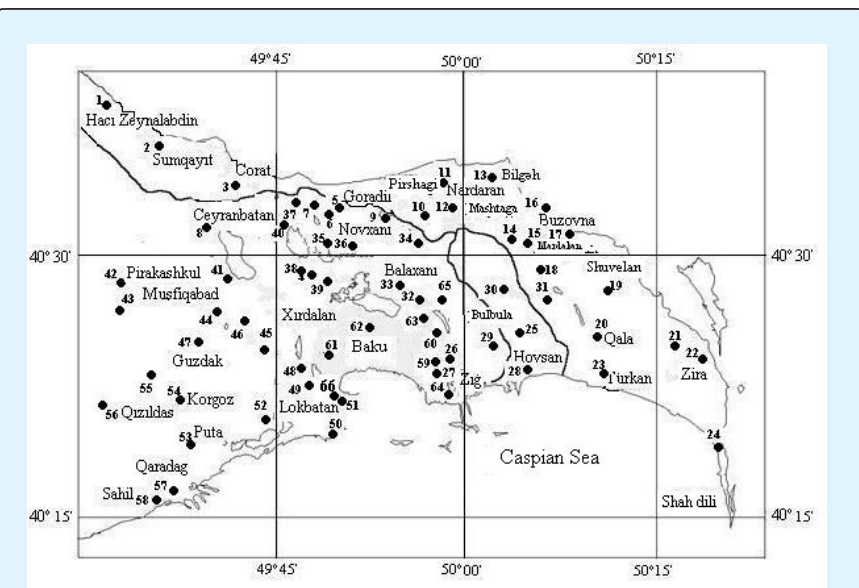

Map 1: Distribution of Cyrtopodion caspius on Absheron peninsula.

Activity of Caspian gecko in March, April and October is daytime. And from May to September, the activity is twilight and night (Figure 2). In recent years, a lot of constructive, industrial and communicative works have been carried out on Absheron peninsula [1]. In this regard, Caspian bent-toed gecko is widespread on Absheron Peninsula [2].

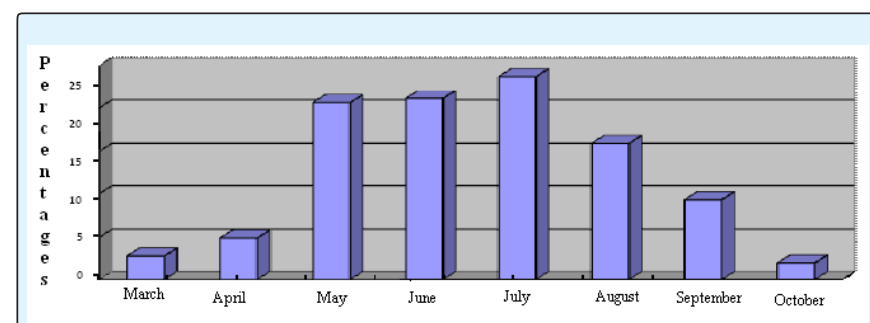

Figure 2: Percentage of meet's with Cyrtopodion caspius, by months, on Absheron peninsula.

Snake-eyed lizard Ophisops elegans Menetries, 1832 is widely spread on Absheron Peninsula (Map 2). For the first time in 1830, it was marked by E.P. Menetriem in settlements of Mashtagi and Buzovna.

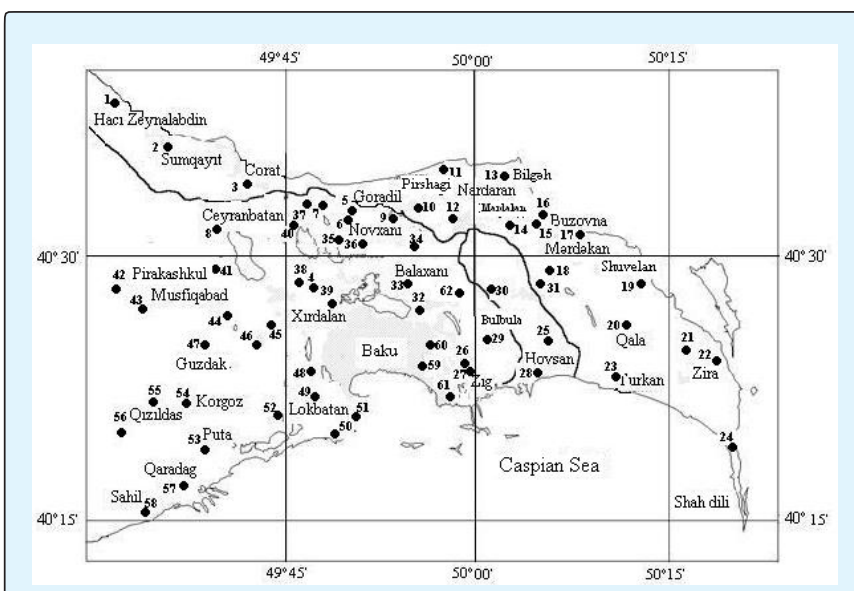

Map 2: Distribution of Ophisops elegans on Absheron.

Ophisops elegans adapts well to semi-desert climatic conditions Ananjeva NB, et al. [3] and has high resistance to cold and environmental pollution (Figure 3 ).

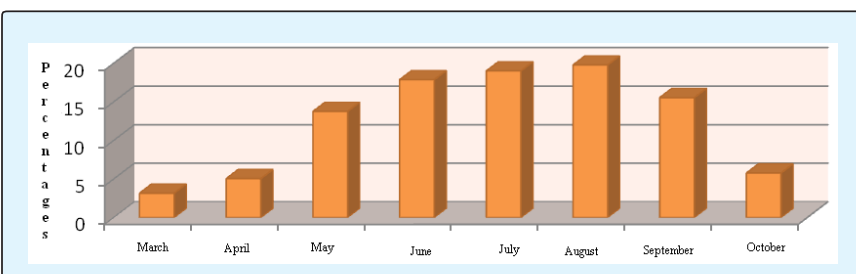

Figure 3: Percentage of meet's with Ophisops elegans, by months, on Absheron peninsula.

Eremias velox Pallas, 1771: It is assumed that the lizard that was found in 1832 by Menetria EP, also called Podares velox Wagh, is snake-eyed lizard. In addition, Kessler KF [4] noted in his writings that in 1878 he brought this species for Absheron peninsula. Today, this 
species is very common on Absheron peninsula [1] (Map 3).

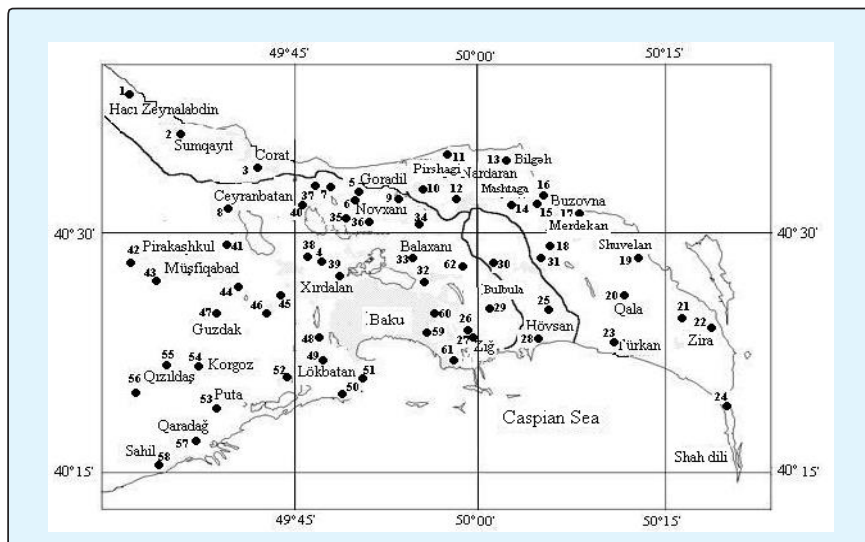

Map 3: Distribution of Eremias velox on Absheron.

Rapid racerunner is a small lizard (approximately 45$67 \mathrm{~mm}$ in length) [5]. This lizard is widely distributed in arid and semi-arid areas of Absheron. Subspecies of $E$. $v$. caucasica Lantz, 1928 inhabits on the peninsula (Figure 4).

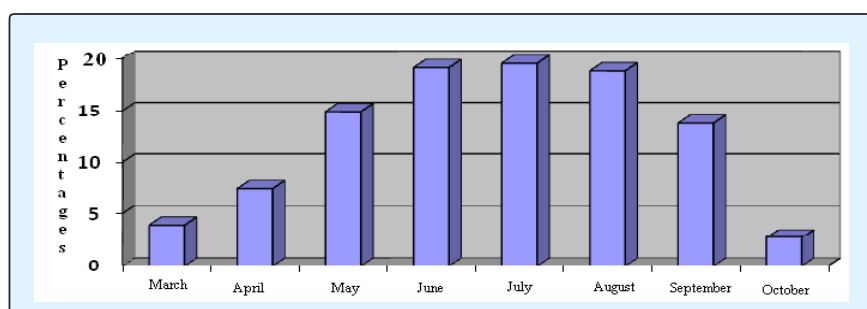

Figure 4: Percentage of meet's with Eremias velox, by months, on Absheron peninsula.

Schneider's Skink Eumeces schneideri (Map 4): In 1875 Grimm emphasized in his research's finding E. schneideri near Baku. Subspecies of E. s. princeps inhabits on the peninsula.

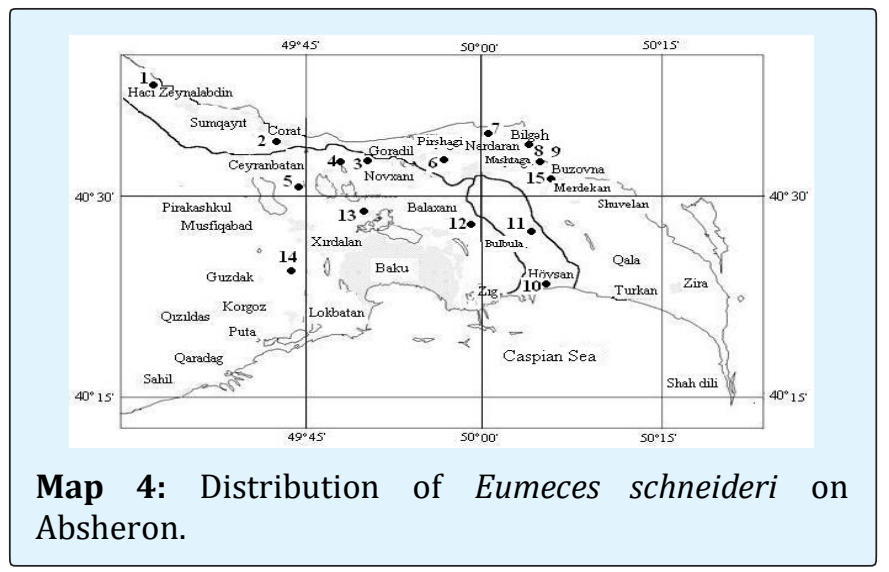

In Absheron, Schneider's skinks are found in dry, rocky steppes and ruins [1] (Figure 5).

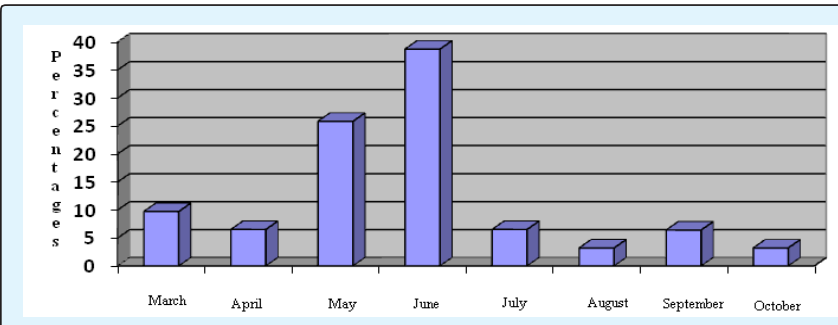

Figure 5: Percentage of meet's with Eumeces schneideri, by months, on Absheron peninsula.

Steppe-Runner Eremias arguta (Map 5): The subspecies of this species, E. a.deserti lives on Absheron Peninsula. For the first time, Menetrie noted this lizard in 1930 near Baku. In 1878, K.F. Kessler caught a representative of this species near Baku and named it $E$. pardalis. This species was widespread on Absheron peninsula.

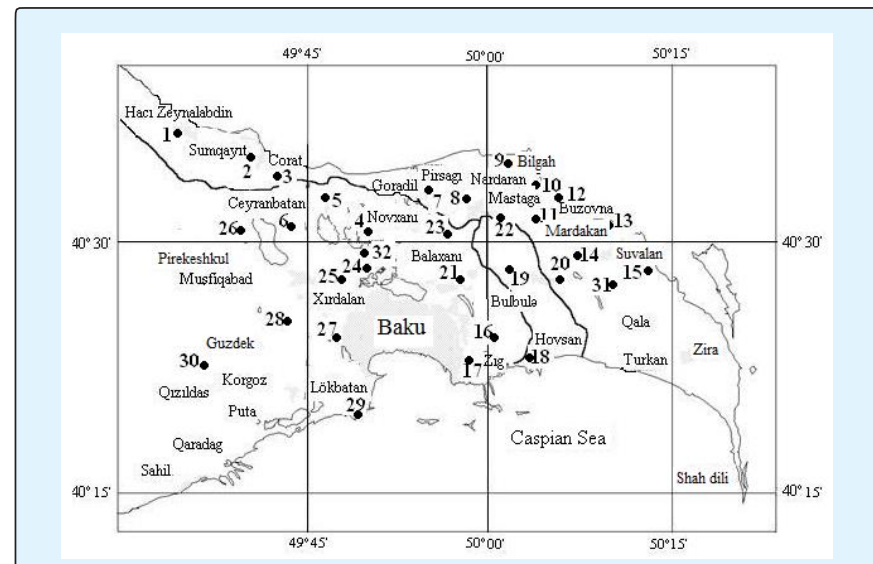

Map 5: Distribution of Eremias arguta on Absheron.

Steppe-Runner is very sensitive to the surrounding effects (Figure 6) and it can easily be caught by enemies and therefore, in recent years its number has significantly decreased.

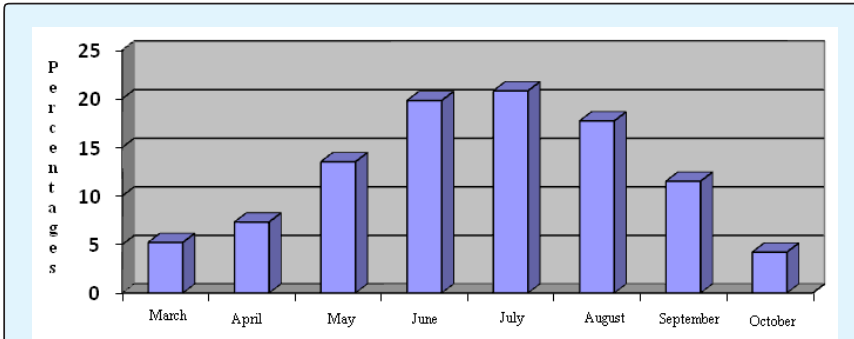

Figure 6: Percentage of meet's with Eremias arguta, by months, on Absheron peninsula. 


\section{International Journal of Zoology and Animal Biology}

Caucasian Agama Laudakia caucasia (Map 6): For the first time this lizard was marked by Eichwald on rocky places near the city of Baku. This well-spread species was once again noted in 1913 by B A Dombrovsky.

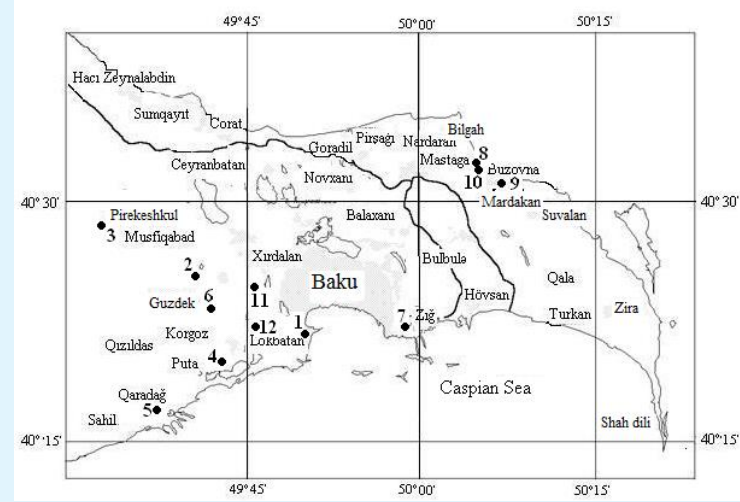

Map 6: Distribution of Laudakia caucasia on Absheron.

On Absheron Peninsula, subspecies of this species L.c. caucasia [6] can be found now days. To date, this lizard can be found in the mountainous areas of peninsula (Figure 7).

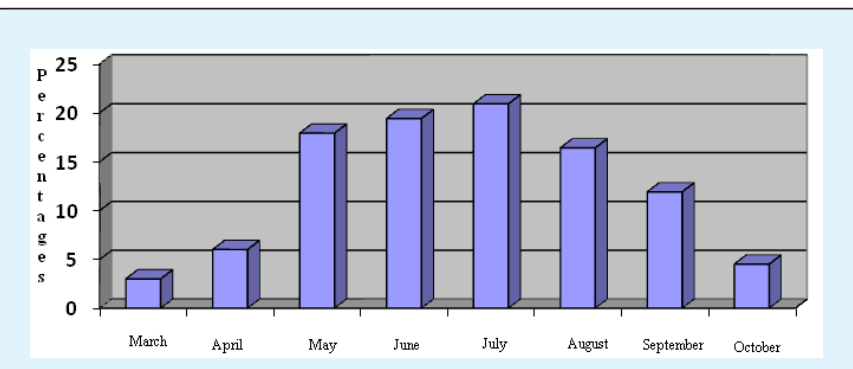

Figure 7: Percentage of meet's with Laudakia caucasia, by months, on Absheron peninsula.

Caspian Green Lizard- Lacerta strigata (Map 7): AM Nikolsky, et al. notes that for the first time this lizard, was discovered by Menetrie near the Baku in the early 19th century and called it Lareta quinquevitto. But this is not true, since the ecological environment of Absheron Peninsula was not suitable for this species two centuries ago. These lizards are not able to live in a semi-desert climate, so they could be brought after a plant environment appeared in this area $[7,8]$.

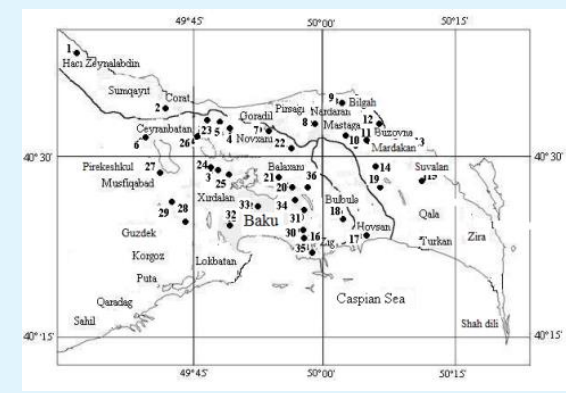

Map 7: Distribution of Lacerta strigata on Absheron.

The first time this species was marked by AM Alekperov in 1966 [9]. He found two representatives of this species in the village of Razin. Now you can meet Caspian Green Lizard at dachas and parks (Figure 8).

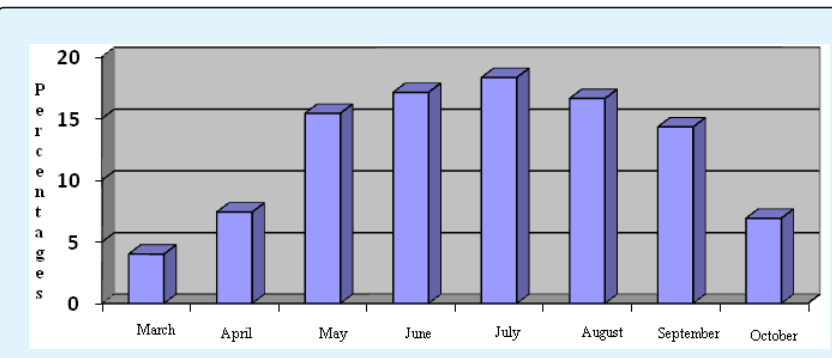

Figure 8: Percentage of meet's with Lacerta strigata, by months, on Absheron peninsula.

\section{Conclusion}

On Absheron Peninsula, 7 species of lisards Eremias velox, Eremias arguta, Ophisops elegans, Lacerta strigata, Laudakia caucasia, Eumeces schneideri, Cyrtopodion caspius including to 4 families, Agamidae, Scincidae, Gekkonidae and 6 genera, Ophisops, Lacerta, Laudakia Eumeces Cyrtopodion live [10-12]. From them six species well adapt to modern ecological conditions and one other species of lizards is seldom met on Absheron Peninsula. The most common species of lizard in Absheron peninsula is the Caspian bent-toed gecko $[13,14]$. In addition to these species, Ablepharus pannonicus is found only on islands near the peninsula. All species of Absheron are oviparous. Most members are small size and are insectivorous.

\section{References}

1. Najafov JA, Hashimov RT (2010) Comparative morphology and anatomy of the locomotors system of 


\section{International Journal of Zoology and Animal Biology}

the Eremias velox (Pallas 1771) and Macrovipera lebet ina. Scientific and Theoretical Medical Journal Morph ology 137(4): 139.

2. Hashimov RT (2010) The Reptiles of the Absheron Peninsula in Modern Ecological Conditions. Works of the Society of Zoologists of Azerbaijan 2: 863-868.

3. Kyriazi P, Poulakakis NP, Lymberakis G, Mantziou PA, Crochet CS, et al. (2005) Molecular Phylogeny and Biogeography of Circum Mediterranean Populations of Ophisops elegans (Sauria: Lacertidae) Inferred from Mitochondrial Sequence Data. Societas Europaea Herpetologica (SEH) Programme and Abstracts 13th Ordinary General Meeting Bonn, Germany, pp: 69.

4. Alekperov AM (1978) Amphibians and reptiles of Azerbaijan. Baku, Elm, pp: 264.

5. Leviton AE, Anderson SC, Adler K, Minton SA (1992) Handbook to Middle East Amphibians and Reptiles, Contributions to Herpetology No. 8. pp: 252.

6. Moody SM (1980) Phylogenetic and Historical Biogeographical Relationships of the Genera in the Family Agamidae (Reptilia: Lacertilia). PhD thesis, University of Michigan, Ann Arbor.

7. Ananjeva NB, Orlov N (2005) Lizards of North Eurasia. Reptilia (GB) 38: 54-63.

8. Firouz E (2005) Habitat Suitability \& Connectivity of Alborz Wild Sheep in the East of Tehran, Iran the Complete Fauna of Iran $1^{\text {st }}$ (Edn.), London and New York 6(6).
9. Ananjeva NB (2008) Taxonomic, Morphological and Ecological Diversity of Asian Agamids (Agamidae: Acrodonta: Sauria: Reptilia). 1st International Symposium on Agamid Lizards. Insights from the Agamidae, Zoologisches Forschungs museum Alexander Koenig, Bonn, Germany, pp: 15.

10. Ahmadzadeh F (2004) A preliminary study of the Lizard fauna and their habitats in Meshkinshahr district. Environmental Sciences 1(2): 39-44.

11. Ananjeva NB, Orlov NL, Khalakov RG, Darevsky IS, Ryabov SA, et al. (2004) Pensoft Series Faunistica: Colored atlas of the reptiles of North Eurasia (taxonomic diversity, distribution, and conservation status), Zoological Institute of the Russian Academy of Sciences, St. Petersburg.

12. Klug M (1991) Checklist of gekkonoid lizards. Smithsonian Herpetological Information Service 85: 1-36.

13. Macey JR, Ananjeva NB, Wang Y, Papenfuss TJ (2000) Phylogenetic Relationships Among Asian Gekkonid Lizards Formerly of the Genus Cyrtodactylus Based on Cladistic Analyses of Allozymic Data: Monophyly of Cyrtopodion and Mediodactylus. Journal of Herpetology 34: 258-265.

14. Scherbak NN, Akhmedov SB (1990) Systematics and geographical variability of the long-naked skink Eumeces scheideri (Sauria, Scincidae). Zoology Bulletin 1: 23-28. 